\title{
„ILY INTÉZKÖDÉSEK MELLETT IMMÁR NEM LESZ SZÜKSÉG ÁLLANDÓ KATONASÁGRA, 'S MÉGIS LESZ ELÉG JÓ KATONA" - A KATONAPOLGÁR IDEÁJA SASKU KÁROLY REPUBLIKÁNUS ÉRVELÉSÉBEN
}

\section{Szerzők:}

Gődér Attila

Debreceni Egyetem

Szerző e-mail címe:

attila.goder.gr@gmail.com

\section{Lektorok:}

Velkey Ferenc (habil.PhD)

Debreceni Egyetem

Mező Ferenc (PhD)

Eszterházy Károly Katolikus Egyetem

...és további két anonim lektor

\begin{abstract}
Absztrakt
A tanulmány a reformkor egyik kevéssé ismert szerzőjének, Sasku Károlynak a politikai témájú műveinek eszmetörténeti elemzésével foglalkozik. Sasku Károly korának egyik igen művelt és sokoldalú karaktere volt. Volt mérnök, ügyvéd, filozófus, nyelvész. Kalandos élete születési helyéről, Felsőbányáról előbb Debrecenbe, majd a fôvárosba sodorta, ahol általam vizsgált múveit is alkotta. Ezekben arra a kérdésre keresi a választ, hogy milyen módszerrel érhetô el az emberiség legnagyobb részének legnagyobb boldogságának megteremtése. A kérdésre alapvetően republikánus választ ad: olyan közösségi kereteket kell létrehozni, melyben az egyén szabadsága biztosított, boldogságkeresését sem polgártársai, sem az állam nem hátráltathatják. Ebben a konstrukcióban kitüntetett szerep jut a katonapolgárnak, aki önfeláldozóan védi hazáját. A tanulmány az eszmetörténeti áttekintés mellett ennek a katonapolgárnak ideájának a részletesebb kibontására törekszik.
\end{abstract}

Kulcsszavak: Sasku Károly, republikanizmus

Diszciplina: történettudomány

\begin{abstract}
"WITH SUCH ACTIONS, IT WILL NOT BE NEEDED FOR A PERMANENT MILITARY BUT WILL BE ENOUGH SOLDIERS" - THE IDEA OF „CITIZENSOLDIER” IN THE REPUBLICAN ARGUMENT OF KAROLY SASKU

This study is about Károly Sasku, who was an engineer, lawyer, philosopher and a linguist. In some of his works he deals with the subject of achieving happiness on a personal, but also on a community level. His argument is essentially republican: the society's job is to ensure that the individual can pursue his happiness, without the threat of any intervention or coercion. In this
\end{abstract}


concept, the idea of „citizen-soldier” got a very important role: even at the cost of his own life, he defends his country. The aim of this paper is to analyze Sasku's intentions and explore the concepts and ideas behind his argument, taking into account the tools of history of ideas.

Keywords: Károly Sasku, republicanism

Discipline: History

Gődér Attila (2021): „Ily intézködések mellett immár nem lesz szükség állandó katonaságra, 's mégis lesz elég jó katona" - A katonapolgár ideája Sasku Károly republikánus érvelésében. Lélektan és hadviselés - interdiszciplináris folyóirat, III. évf. 2021/1. szám. 69-81. doi: 10.35404/LH.2021.1.69

E tanulmány Sasku Károly politikai témájú mûveinek vizsgálatát foglalja össze, különös tekintettel a szerző érvelésében megragadható republikánus jegyekre és annak összefüggéseire a honvédelem problematikájával.

Mindez a modern eszme-történet vonatkozásában Quentin Skinner által megfogalmazott tanácsokat figyelembe véve fog megtörténni. Fontosnak tekinthetjük tehát a szerzői szándék megállapítását, és azt, hogy a szöveget ne önmagában, zárt egészként értelmezve, hanem térben és időben elhelyezve vizsgáljuk, feltárva azokat a diszkurzív kereteket, amikbe illeszkedik (Skinner, 1997).

Azt a ,játéktárat” akarom tehát feltérképezni, melyet Sasku felhasznált a társaság általa ideálisnak tartott verziójának megkonstruálása során. Ha elfogadjuk a ,játéktár” fogalmának Takáts József Itamar Even-Zohar irodalomtudóstól vett (Takáts, 2014. p. 14.) értelmezését, akkor a következőt értjük alatta: „a játéktár azon szabályok és elemek összességét jelöli, amelyek egy terméknek [itt: szövegnek, cselekvésnek, tárgynak] mind megcsinálását, mind felhasználását irányítják.” Ezen „sza- bályok és elemek" (pl. fogalmak, beszédmódok) vizsgálata tehát e dolgozat fő célja.

Fontos megérteni, hogy mindez nem tekinthetô reprezentatív jellegűnek. Sasku munkásságának tanulmányozása nem elegendő ahhoz, hogy általános következtetéseket vonjunk le belőle, arra ugyanakkor elegendő, hogy egyfajta kortárs szűrőn keresztül vizsgáljuk a korabeli politikai diskurzusok egyes kulcsfogalmait, az egyes politikai beszédmódok megjelenési formáit.

Sasku a 19. század első felének az utókor által kevéssé ismert szereplője. Éppen azért lett kiválasztva munkássága jelen tanulmány tárgyául, mivel nem tartozott a korabeli diskurzus fősodrához. Sasku nem munkáinak eredetisége és meglátásainak korszakalkotó jellege miatt lehet érdemes a figyelmünkre (bár ezeknek sincs teljesen híján), hanem azért, mert ezek tanulmányozásán keresztül betekintést nyerhetünk abba, hogyan viszonyult egy korabeli értelmiségi, műveltnek tekinthető személy a korabeli közbeszéd olyan meghatározó fogalmaihoz, mint a közboldogság, és hogyan csapódtak le benne a kor nagy for- 
mátumú gondolkodói által megfogalmazott gondolatok.

Sasku politikai témájú múveivel legjobb tudomásom szerint történeti szakmunka eddig nem foglalkozott. Sasku kalandos életpályájáról született egy újabb elemzés, Deák Ágnes és Kövér György: Egy sorsüldözött rögeszméi - Sasku Károly (1807-1869) című tanulmánya, mely főleg a szerző életének a forradalmat követő, zavaros időszakával foglalkozik, és mely munka ezen kutatás számára is fontos információ- és inspiráció-forrásként szolgált. Az életpálya rekonstrukcióját egyrészt a fent említett munkákra, másrészt egyéb forrásokra támaszkodva tesszük meg.

\section{Sasku Károly \\ életpályájának rövid ismertetése}

Sasku Károly Késtsináló Károly néven látta meg a napvilágot, 1806-ban (Szinnyei), Felsőbányán, nemes Késtsináló István fiaként. (Deák és Kövér, 2012). Hogy a későbbiekben miért tért át a Sasku név használatára, nem ismert, a Debreceni Református Kollégiumba mindenesetre még Késtsináló Károly néven iratták be. Nem maradt ránk túl sok forrás életének ezen időszakáról, bizonyítványai mellett csupán egy levél, melyben édesapja egy alapítványi ösztöndíj odaítélését kérvényezi a fia számára a Debreceni Professzorátustól, melyet a fiú szorult anyagi helyzetével és jeles tanulmányi előmenetelével indokol (TtREL: II. 1. C. 3. Kollégiumi Igazgatói Iratok: 1821500.) Kollégiumi tanulmányait bizonyítványa alapján eminens tanulóként sikerült befejeznie (Deák és Kövér, 2012). 1829-től 1831-ig a kisújszállási iskola rektoraként dolgozott, itt már Sasku v. Késtsináló Károly néven hivatkoznak rá (Net1).

Ezt követően Pesten jogi tanulmányokat folytatott, 1833-ban ügyvédi vizsgát is tett, majd a selmeczi akadémián tanult, majd pedig Pesten folytatott mérnöki tanulmányokat a Magyar Királyi Egyetemen. Ezután Országos Építészeti Főigazgatóságnál dolgozott gyakornoki állásban, majd a Duna Mérési Intézetnél kapott állást. Később 1842-től 1844-ig a máramarosszigeti református liceum tanáraként tért vissza a pedagógusi pályára. 1844 ismét önkéntesként dolgozott.

1846-ban a Tiszavölgyi Társulatnál kapott segédmérnöki állást (Deák és Kövér, 2012). Itt a központi választmány egyik főmérnöki pozícióját szerezte meg (Kovács, 1889) és vélhetően itt ismerkedett meg gróf Széchenyi Istvánnal is, akivel igen jó munkakapcsolatot sikerült kialakítania, olyannyira, hogy a szintén a gróffal utazó Kovács Lajos egyenesen a gróf kedvenc mérnökének nevezi. (Kovács, 1889).

Az 1848-as események idején az új magyar kormány lelkes támogatója, a fegyveres szabadságharc idején a honvédséghez is csatlakozik. Lónyay Menyhért, egykori tanítványa elismeréssel beszél Sasku szabadságharc idején tanúsított bátorságáról (mely szerinte éles kontrasztban állt Sasku korábbi gyáva természetével, és mely változást ő a nagy idők hatásának tudott be - Budapesti Szemle, 1885, 42. kötet, 100-102. szám, p. 350 - 351.). A világosi fegyverletételkor már a fóhadnagyok között találkozunk a nevével (Deák és Kövér, 2012).

Saskut igen megviselték a szabadságharc leverését követő megtorlás évtizedei. Pesten 
élt, nehéz körülmények között, melyeket csak rokonaitól kapott kölcsönök tettek kissé elviselhetőbbé. Ekkoriban mentális állapota megromlott, folytonosan a rendőrség vélt vagy valós üldözésétől tartott. Komoly pszichés problémákkal küzdött, mindenhol a rendőrség ôt figyelő ügynökeit sejtette, akik véleménye szerint a legváltozatosabb módszerekkel (pl. mérges gázokkal, izzó fémpálcákkal, zajkeltéssel stb.) kínozták (bővebben lásd Deák és Kövér, 2012 tanulmányát). Ennek ellenére az MTA-nál korrektori majd főkorrektori állást kapott, mely hivatalát tisztességesen töltötte be egészen 1869-es haláláig (Deák és Kövér, 2012).

Sasku közírói tevékenységének java része azonban még jóval ezen időszak előttre, az 1840-es évekre esik. A szerzô rendkívül szerteágazó műveltsége és nyelvtudása (beszélt németül latinul, görögül, héberül, franciául, angolul, olaszul, portugálul és spanyolul is) lehetővé tették számára, hogy több területen véleményt formálhasson. A politikai kérdések mellett foglalkozott pedagógia-elméleti, művészet-elméleti témákkal és mértani problémákkal is, illetve lefordította Dionysius Lardner Amerikai Egyesült Államok történetéről szóló munkáját magyar nyelvre (Závodszky, 1992).

\section{Sasku ideális „társaság” keretrendsze- rének megteremtésével foglalkozó mü- veinek elemzése}

A három itt vizsgált mú a „Törvények alaptudománya” (Sasku, 1841), a „A kelet és nyugat népe és a Köz Intézetekről”' (Sasku, 1842a) és a „Boldogságtudomány, vagyis mimódon teheti magát az emberi nemzet lehető legbol- dogabbá?” (Sasku, 1842b) a szerző szerint egy koherens egészként olvasandó, erre többször is felhívja a figyelmet a „Boldogságtudomány” olvasása közben. A három munkában Sasku azt a célt tűzi ki maga elé, hogy megtalálja a lehető legideálisabb „társasági” modellt, mely egyszerre garantálja tagjainak szabadsághoz és boldogsághoz való jogát.

Sasku érvelése főként az utilitarizmus felől közelíti meg a politika területét, ideális állapotnak a lehető legnagyobb rész lehető legnagyobb boldogságát nevezi. Sasku számára a boldogságkeresés nem képzelhető el az egyén szabadságának biztosítása nélkül. A szabadság azonban az egyén számára csak a közösségben nyer értelmet, hiszen társasági kapcsolatok nélkül nem érheti el a boldogságnak azt a fokát, amit a társasági lét tesz lehetôvé számára. Fontos kiemelni tehát, hogy a társaság létét Sasku annak hasznosságával indokolja. Ô maga a következőképpen fogalmazza ezt meg:

„Az ember, többekkel együtt, vagyis társaságban élve sem szün meg egyszersmind külön személyben is ember lenni, s annálfogva ott is ön boldogsága neki egyedüli czélja; sőt a társasági életet is csak egyedül azért kívánja, hogy boldogsága a társaságban biztosítva, 's boldogulhatásra több alkalma legyen." (Sasku, 1842b, 5. o.)

Látható ugyanakkor, hogy Sasku érvelése alapvetően republikánus logikát használ. Nála az egyén szabadságának legfőbb garanciáját a társasági keretek adják, melyek a tásaság tagjainak jóváhagyásával jöttek létre, és 
legitimációjukat is a társaság tagjainak megelégedettsége adja. Emiatt folyamatosan módosíthatóak, amennyiben a társaság tagjai ezt szükségesnek látják. Sasku tehát nem ismeri el az ósi alkotmányra építkező érvelések legitimitását, hiszen azok ütköznek az általa hangoztatott „legnagyobb rész legnagyobb boldogsága" utilitarista elvével.

Az ôsi alkotmányra való hivatkozás politikai nyelvét beszélő szerzők a társaság törvényeit az ősöktől örökölt állapotok megőrzésének fontosságát hangsúlyozzák, a közösség tagjainak jogait pedig az alapító tagoktól származtatják, és ennélfogva az örökösök egyfajta kötelezettségeként tekintenek azok védelmére. A közösség létrejöttekor fennálló állapotok és saját koruk viszonyai között folytonosságot feltételeznek (Takáts, 2014).

Ezzel szemben Sasku értelmezésében a társaságnak mindig az adott kor elvárásainak kell megfelelnie, és nem valamiféle elvont, idealizált közösségi forma védelmét jelöli meg a „társaság” alkotmányának feladataként, hanem azt, hogy lehetővé tegye a tagjai számára a közösségen belüli boldogság elérését. Ehhez biztosítania kell a közbátorságot, mely ebben a kontextusban a szabadság egy negatív formáját jelenti (Berlin, 1969.), mely alatt a szerző az egyén cselekedeteinek szabadságát, a külső korlátozó tényezők hiányát érti. Mint írja: "Tudni kell ugyanis, hogy az emberek nem csak természeti jussaik azaz személyi vagyomi és cselekvési szabadságok biztosítása vagyis bátorság végett kivánkoznak inkább társasági életben élni, mely bátorság azonban már maga is nagy jó rájok nézve, mert noha e' szabadsággal a' társaságon-kivül is birnak, de felőle biztosítva nincsenek: hanem a' gyönyörüségek végett is" (Sasku,1842b,11. o.).

Látható, hogy Saskunál a társaság fő feladata az, hogy biztosítsa a szabadságot, nem pedig az, hogy megteremtse azt. Fontos különbség, ugyanis az utilitarizmus egyik első gondolkodója, Jeremy Bentham például kifejezetten ellenségesen viszonyult a természeti jogok fogalmához. Vélekedése szerint ugyanis a jogok csak egy közösség konstrukciói, az egyén önmagában nem rendelkezik jogokkal, és ugyan ebben a közösségen kívüli állapotában is formálhat igényt a jogokra, azokat csak a közösségen belül szerzi meg, a közösség megegyezése nyomán (Demeter, 2018).

Emellett mint a fentebbi idézetből is kiderül, Sasku nem csupán a „közbátorság” biztosításával magyarázza az egyén társasági életre való hajlandóságát, hanem a közösségi kapcsolatokra is ,gyönyörűségekként”, vagyis az egyén boldogságának forrásaiként tekint.

Fontos azonban, hogy a „társaság” nem kényszerítheti tagjait a boldogságra, pusztán a lehetőséget kell biztosítania számukra annak eléréséhez. A kényszerítés tehát, akárcsak John Lock-nál (Farre, 1979), a szabadság végét jelenti, a szabadság nélkül pedig az egyén nem érheti el a boldogságot. Ahogy Sasku fogalmaz: „mert a boldogság csak képzeleti név, mely valósággal nem egyébb megelégödésnél, akkor elégszünk meg pedig, ha azt elérjük, vagy olyat érünk-el, a' mit önkint kivántunk, nem pedig a mire kínszerítődtünk" (Sasku, 1842b, 8. o.).

Látnunk kell tehát, hogy a közösség autoritása az egyén boldogságkeresésébe nem avatkozhat be, hiszen azzal ellehetetlenítené azt. A „társasági” keretrendszer egyetlen feladata 
tehát, hogy a lehetőséget teremtse meg a polgárok számára a boldogság eléréséhez. Sasku szerint ugyanis a társaság minden tagjának egyet kell értenie a társaság törvényeivel, hiszen, ha ez nem következik be, úgy egyesek nem tagjai, csupán szolgái a társaságnak, akik szolgai státuszukkal érthető módon elégedetlenek, vagyis következésképpen a „társaság" fenntartásában sem érdekeltek. Ez a szerző szerint egy negatív folyamat, hiszen republikánus hagyományoknak megfelelően a belső megosztottságot tartja a legnagyobb veszélynek a társaság számára. A belső harmónia megteremtése tehát a társaság legfőbb feladata, ehhez pedig elengedhetetlen a törvény előtti egyenlőség. Azonban Sasku szerint senki sem kényszeríthető a társaságon belüli létre, mindenki számára biztosítani kell a kiválás lehetőségét. Ez egyben azt is jelenti, hogy a külvilághoz a társaság csak pacifista szemlélettel viszonyulhat, hiszen hódításai esetén csak diszharmónia keletkezne a társaság belső rendjében, az új tagok ugyanis nem önszántukból csatlakoznának (Sasku, 1842b).

Ez nem jelenti ugyanakkor azt, hogy a tagoknak ne kellene érteniük a fegyverforgatáshoz. Sasku meglátása szerint a polgárok kötelessége megvédeni a társaságot, mint jogaik és szabadságuk legfőbb védnökét, így aztán már az iskolai nevelésnek is tartalmaznia kell bizonyos katonai alapismereteket, játékos formában megtanítva a különböző hadi mozdulatokat és azok értelmét a fiúknak, 15 éves koruk környékén pedig 2 éves általános hadi képzésben kell részesülniük. Mindez lehetôvé teszi, hogy felnőve a „társaság” katonai ismeretekben jártas polgáraiként védelmezhessék azt a különböző fenyegetésektől. A „társaság” fegyveres védelme ugyanis kötelezettség, a polgárjog felétele. (Sasku, 1842b). Látható, hogy Sasku itt bizonyos értelemben leszúkíti a korábban széles jelentésmezővel bíró „,társaság” fogalmát, és egyre inkább a korabeli „respublika”, vagyis köztársaság-fogalomhoz kapcsolódó tartalommal tölti azt fel.

Meg kell jegyezni, hogy a közösség fegyveres védelmének fogalma nemcsak kötelezettségként merül fel, hanem jogként is, hiszen minden polgár egyenlő jogait és kötelezettségeit tekintve a társaságon belül, vagyis a közösség fegyveres védelmének joga mindenkit megillet.

Érdekes mindezt párhuzamba állítani a korabeli nemesi jogfelfogással. Az adómentesség, a közügyekben való részvétel jogát a haza fegyveres védelmének kötelezettségével magyarázta (Poór, 2003). Sasku a jogokat a társaság védelmének kötelezettségéből levezető érvelést megtartja, azonban nem egy szûk réteg feladatává teszi azt, hanem minden polgárévá. Nála tehát a polgárok katonák, és a katonák polgárok is egyben. Mindezt részben a hadsereg moráljának szinten tartásával is indokolja, hiszen a zsoldossal ellentétben, aki csak vagyonért küzd, az ilyen polgárkatonák a társaság védelméért szállnak hadba, amit a szerző erkölcsileg felsőbbrendű indokként értékel. Mint írja: „de nem is sokat bízhatni rendesen az idegenek segítségébe, kik ily alkalommal inkább csak ön hasznokat keresik, mint azon társaságét, mely segítségökre szorult." (Sasku, 1842b, 80. o.)

Sasku érvelése egyáltalán nem egyedülálló a korszakban. A forradalmi majd a napoleoni háborúkat követően a hadtudományok szakértői megpróbálták feltárni az okokat, melyek 
sikeressé tették a francia hadsereget. Kiss Károly 1840-es akadémiai székfoglalóján például a következő címmel tartott beszédet: „Mi okozta a franczia köztársaság harcnyereségeit? Győzedelmeinek mi adott olly hatalmas befolyású sikert". Ebben a beszédében sorra veszi a koalíciós vereségek lehetséges okait, és arra jut, hogy a legfőbb problémát azok hadszervezetének elmaradottsága okozta (Ács, 2005).

Ennél is tovább ment az MTA egy 1846-os nagygyúlésén tartott székfoglaló beszédében Horváth Mihály történész, aki a magyar hadtörténet négy korszakának (az Árpádok háborúi, az Anjouk uralkodásától 1526-ig terjedő időszak katonai konfliktusai, az ettől a dátumtól 1715-ig, vagyis az állandó hadseregek megjelenéséig, illetve az 1715-tôl a maga koráig tartó időszak) ismertetése után kifejti, hogy az utolsó időszakban a hadügy területén nem történt érdemi fejlődés, így a reformokat sürgető álláspontra helyezkedik, és kijelenti: „,csak a polgárivédhad-rendszer lehet egyedül biztos horgony, mellynek hatalmas ereje a nemzet sajkáját az élet és a szabadság öblében fentarthatja” (idézi: Ács, 2005, 77. o.). Látható tehát, a Sasku által bemutatott, polgárokból verbuvált, milícia jellegű hadsereg előnyeit mások is felismerték a korban.

Sasku vélekedése szerint ugyanakkor nemcsak a külső fenyegetések miatt hasznos, ha a „társaság” tagjai készek és képesek megvédeni jogaikat, akár fegyveres erővel is. Felléphetnek ugyanis olyan személyek vagy csoportok, akik ugyan tagjai a társaságnak, ám annak törvényei nem tartják be, sőt, más polgárokat is korlátoznak szabadságukban. Sasku szerint, ha a fegyveres védelem feladatát a közösség egy külön erre kijelölt csoportra bízza, az könnyedén zsarnokságra használhatja fel ezt a kiváltságát (Sasku, 1842b, 83. o.).

A zsarnokságot pedig a szerző a társaságra leselkedő egyik legnagyobb fenyegetésként értelmezi, hiszen azáltal, hogy megfosztja egyes tagjait a szabadságától, egyben boldogsághoz való joguktól is megfosztja őket.

A társaságnak tehát érdekében áll a tagjai boldogságának minél nagyobb szintre emelése, ezért cserébe azok érdekeltek lesznek az előnyös állapotok konzerválásában, vagyis a társaság védelmében. Sasku értelmezésében tehát a társaság szabad és egyenlő emberek szerveződése, akik egyéni szabadságjogaik biztosítása és oltalmazása érdekében lépnek szövetségre egymással. Látható tehát, hogy Sasku racionális magyarázatot keres a társaság létrejöttére, és ezt a magyarázatot ő a szabadság kölcsönös biztosításában találja meg. Igen hasonló módon gondolkodott a kérdésben Kossuth Lajos is. Egyik gyarkan hangoztatott frázisa „A szabadság olly kimeríthetlen kincs, melly azáltal, hogy véle többen osztoznak, sem fogy, sem gyengül, sőt nő, sőt erősödik." (idézi: Miru, 2011, 26. o.) volt, mely elvre építette fel Sasku is az ideális társadalomról alkotott nézeteit.

A kérdés elvi hátterének bemutatása után Sasku bemutatja, hogyan is kellene ezeket a gyakorlatba átültetni, vagyis létrehozni egy „társaságot”, mely képes garantálni a közszabadságot.

A közigazgatás és a törvényhozás megszervezésekor Sasku rendkívül fontosnak tartja a hatalom megosztását: „egyszóval a végrehajtást, el kell a' törvényhozói hatalomtol választani; úgy hogy a törvényhozó gyülés 
tehessen 's tegyen ugyan minden átalános rendeleteket az egész társaságra nézve, de maga semmit végre ne hajtson;" (Sasku, 1842b, 34. o.).

A végrehajtó hatalmat is tovább osztja a bíróságokra és a közigazgatásra. Látható, hogy a hatalmi ágak szétválasztásának Montesquieu-i modelljét vette át, melyben a hatalmi ágak egymást is felügyelik. Sasku ezt a zsarnokság elleni védekezés érdekében elengedhetetlennek tartja. A választott köztisztviselók jogi értelemben a társaság tagjait képviselik, ennélfogva testületként a törvényhozói gyúlés nem vonható felelősségre az igazságszolgáltatás által, ugyanakkor személyükben a képviselők továbbra is a társaság törvényei alá vannak rendelve, így Sasku igyekszik feloldani azon ellentmondást, hogy hogyan felügyelhesse a hatalom azon képviselőket, akik a társasági szabályrendszer korlátain túllépve próbálnak meg visszaélni hatalmukkal. (Sasku, 1842b, 38. o.).

Sasku ugyanakkor úgy véli, a polgárok minél nagyobb arányban részesedhetnek a köztisztviselői pozíciókkal járó megbecsülésből, annál kisebb az esélye zsarnokság kialakulásának, hiszen így törvényes keretek között élhetik ki az „uralkodás” iránti vágyukat. Látható, a szerző itt a hasznosság felől közelíti meg a problémát, ezért kijelenti, hogy a választópolgárok legnagyobb részét egyben választhatóvá is kell tenni.

Sasku a közigazgatás és a törvényhozás legalsó lépcsőfokaként a helységeket képzeli el, melyek a Thomas Jefferson munkáiban megjelenő wardokhoz (Lévai, 2013, 222. o.) hasonlóan önálló kis köztársaságokként funkcionálnának, saját iskolával, törvényhozással és bírósággal, illetve katonaság egységeit is ezeknek kellene lakosságszámarányosan kiállítaniuk, illetve az adószedés is ezen a szinten történne. Sasku szerint a helyi szinten megválasztott képviselőket érdemeik alapján választják ki polgártársaik, így biztosítva, hogy a társaság vezetése mindig hozzáértő egyének kezében legyen. Sőt, nemcsak a polgári tisztviselők választása történik meg a helységek szintjén, hanem még az egyes tiszteké is a helység kiállította milícia nagyságától függően. Mint írja:

„Minden férfi polgár egyszörsmind katona legyen serdültt korátol kezdve egészen hajlott koráig, addig tudniillik, a midőn már tisztségeket nem szabad viselnie a föntebbiek szerint; 's minden polgári tisztviselő egyszörsmind azoknak, kiknek polgárilag tisztje, katonailag is tisztje legyen. 'S ugyanazért tisztválasztáskor ne csak a föntebb maga helyén eléadott tisztségekre tiszteket, hanem ezeken kivül századosokat, tizedeseket is válaszszanak a polgárok magok közzül” (Sasku, 1842b p. 85.).

Az „alacsonyabb” rangú tisztikar katonák által történő kiválasztásának gyakorlata a Római Köztársaság korába vezethető vissza. A római legionáriusok maguk közül választhatták centurióikat (nagyjából a századosnak megfeleltethető tiszti rang a római hadseregben), és ez egy fontos lehetőség volt a katonák számára a katonai és a társadalmi felemelkedésre, hiszen a centurió rangját viselő katonának akár a római lovagrendbe (a szenátori 
rend alatt elhelyezkedő társadalmi réteg) is volt esélye bekerülni, ha végigjárta a tiszti ranglétrát (Taylor, s.a.).

Nem tudhatjuk ugyanakkor, hogy Sasku hasonló szándékkal javasolja-e a hadsereg alacsonyabb tisztjeinek közvetlenül a legénység által történő választását, az mindenesetre bizonyos, hogy az antik republikánus hatások megjelenése nem meglepő, tekintve, hogy Sasku kollégiumi tanulmányai alatt megismerte az ókori Róma történetét (mint az bizonyítványából is kiderül, lásd a Magyar Tudományos Akadémia Könyvtára. Kézirattár és Régi könyvek Gyűjteménye: M. Ir. Levelezés. 4 - r. 160.). Mindenesetre a magasabb rangú tisztek esetén véleménye szerint a törvényhozó gyúlésre kell bízni a kiválasztásukat. (Sasku, 1842b).

Fontos tehát, hogy a „társaság” a helységek számára minél nagyobb önrendelkezést tegyen lehetővé, hiszen, mint Sasku (1842b, 26. o.) írja: „Az egész társaság valódi alkató részei azonban minden-kor csak az egyes helységek maradnak. A honnan az egész társaság' fö tekintete és gondja mindig az egyes helységek szabadsága és jólléte 's annálfogva boldogsága tartozik lenni".

Itt meg kell jegyeznünk, hogy a jeffersoni mintákkal való hasonlóság valószínúleg nem a véletlen múve, Sasku az Amerikai Egyesült Államok történetével foglalkozó egyik fordításában például ez a megállapítás szerepel: “de Jefferson erre [a szabadság és a függetlenség elérésének céljára] olly országlási elveket épített, mellyeket minden szabad népnek kisebb-nagyobbmértékben el kell fogadnia." (Sasku Károly, 1836, 262. o.).
A helységi szint jelentette alapra épülne fel aztán a társaság szerkezete, a polgárok csak itt tudnának közvetlenül beleszólni a közügyek alakulásába. Sasku szerint ugyanis a közvetlen demokráciának csak ezen a helységi szinten van létjogosultsága, a polgároktól ugyanis nem várható el, hogy folyamatosan informáltak legyenek a társaság egészének közügyeit illetően, a helységek szintjén azonban ez megoldható. Hasonló gondolat figyelhető meg Thomas Jeffersonnál is, aki a köztársaság közigazgatásának felsőbb szintjei (tehát megyei, állami, szövetségi) számára képviseleti demokráciát ajánl, mivel a közvetlent már nem tartja ideálisnak. Emellett a polgároktól eltávolodott magasabb szintek a korrupció elburjánzását is lehetôvé teszik, így az kormányzat ezen szintjeit a „lehető legszűkebb körben kell tartani” (Lévai, 2013, 223. o.).

A decentralizált közigazgatás és a helyi autonómiák ilyen formájú megerôsítése a magyar municipializmussal is párhuzamba állítható, hiszen a polgárok által választott tisztviselők, vagyis a közvetlen demokrácia gondolata egyáltalán nem idegen a korabeli magyar politikai felfogástól. Kossuth például egyenesen úgy tartotta, ,autonom municipialitások nélkül nincsen szabadság" (idézi: Miru, 2011, 56. o.) Igaz, a „,municipium” alatt a korabeli magyar közvélemény a vármegyék szintjét értette, ám a hasonlóság a korabeli municipialista érvelések és Sasku helységekre építkező szabad „társaság-modellje” között mindenesetre jelen van. Az alulról fölfelé építkező, demokratikus modell pedig Jeremy Bentham álláspontjával összhangban. Bentham szerint a különböző kártékony érdekekkel szemben a közérdek leghatékonyabb védelme úgy garantálható, ha 
a lehető legtöbb ember jut választójoghoz. (Áron, 2003).

Saskunál ez a következőképpen jelenik meg: „És ebben áll a társaságtudomány legmélyebb titka 's legerősebb alapja, hogy a társaság képviselőji egyszersmind minden társaknak egyenkint's azok érdekeinek és így az egésznek minden kivétel nélkül képviselőji, megbízottjai legyenek. Úgy hogy a mely társaság némely társakat e képviselésböl azaz a választásbol kirekeszt, ezáltal mind erejét meggyöngíti, mind az elégületlenség által boldogtalanság 's annálfogva enyészet magvait hinti - el ön kebelében, annál nagyabb mértékben, minél több tagjait 's minél inkább rekeszti - ki e képviselésböl" (Sasku, 1842b, 22. o.).

A helységek szintjén aztán a köztisztviselők választása demokratikusan valósulhatna meg, minden felnőtt polgár szavazata ugyanannyit érne. A szerző igyekszik hangsúlyozni, hogy a „társaság” szabadságának érdekében minél szélesebb réteget kell felruházni választójoggal, hiszen csak ez jelentheti a tartós belső rend alapját. Sasku hangsúlyozza, a választójogot a nőkre is ki kell terjeszteni (bár a köztisztviselői posztokra nem tartja őket alkalmasnak, ezt szeszélyességükkel indokolja), hiszen a társaság fenntartásából ők is kiveszik a részüket.

Mindez ismételten utilitarista gondolat, Bentham szintén a hasznosságukra alapozva érvelt a nők választójoga mellett (v.ö.: Williford, 1975, 168-169. o.).

Megfigyelhető, hogy Sasku a törvénykezésben a közösség érdekeinek fontossága helyett az egyén szabadságának biztosítására helyezi a hangsúlyt, viszont nála itt nincs inkonzisztencia, hiszen természetesnek veszi, hogy ha valaki a „társaság” tagja, akkor az érdekei is megegyeznek a „társaság” érdekeivel.

Törvények alaptudománya (Sasku, 1841) című múvében felsorolja a legfontosabb alapjogokat: személyében minden polgár szabad és joga van a gondolati szabadsághoz és szabad véleménynyilvánításhoz, valamint a vagyonával minden polgár szabadon gazdálkodhat. Hozzáteszi ugyanakkor, hogy az egyén szabadsága csak addig érvényesülhet, míg az nem ütközik a közösség szabályaival. Szabadságuk korlátozását azonban a polgárok maguk szabályozzák, mint fentebb említésre került, a polgárok választott képviselőik útján maguk is részt vesznek a törvényhozásban, így a szabályok összhangban állnak igényeikkel. Emellett fontos, hogy a törvényeket mindig betű szerint kell értelmezni, az ítéletek meghozatalakor objetivitásra kell törekedni. Mindezen gondolatok Jeremy Benthamnél is előfordulnak, az angol szokásjogon alapuló kritikájának egyik fő célja éppen a törvényhozás és ítéletvégrehajtás racionalizálása.

Ugyanezen múvében jelenik meg egy másik, antikvitásba visszanyúló republikánus motívum, a földműves életmód felmagasztalása. Saskunál a földműves alakja a republikánus polgári erények megtestesüléseként jelenik meg. Szorgos, életrevaló ember, aki munkájából kifolyólag nem henyélhet, ugyanakkor autonóm is, hiszen nincs kiszolgáltatva a környezetének, létszükségleteit saját forrásból is ki tudja elégíteni. Sasku a „társaság” egyik fő céljaként határozza meg, hogy minél több tagját juttassa földbirtokhoz, és ezáltal lehetővé tegye az önálló, de földjei elhelyezkedése folytán mégis a társasághoz 
kötött polgárok számának gyarapodását (v.ö.: Sasku, 1841, 13-15. o.).

Gazdasági kérdésekben Sasku smithiánus álláspontra helyezkedik, vagyis a lehető legkisebb állami beavatkozás mellett érvel. Ez egyben azt is jelenti, hogy a „társaság” számára egyetlen jövedelemforrást tart hasznosnak, a vagyonadót, mindenfajta egyéb vámot és illetéket alapvetően káros koncepcióként értelmez. Ezt a tagoknak jövedelmüknek megfelelő arányban kell fizetni, és egy felülről lefelé szerveződő rendszer veti ki az országok, államok, megyék és végül helységek szintjén. (lásd: Sasku, 1842, 70-73. o.).

A közintézmények tekintetében Sasku az egyén és a társaság viszonyában a társaság kötelességeit emeli ki. A szerző szerint a társaság születésüktől a halálukig felelős tagjaiért, mivel csak így várhatja el azoktól a védelmet. Ennélfogva a „társaság”-nak kötelessége létrehoznia különböző közintézeteket, többek közt szülészetet, kórházat, közpénzből fizetett ingyenes háziorvosi rendelést, elmegyógyintézetet, sőt, időssek otthonát is létre kell hoznia, és államilag finanszírozott temetkezési szolgáltatást is nyújtania kell. Az itteni szolgáltatások árát azonban a munkaképes tagoknak (tehát az idősseknek és betegeknek nem) le kell dolgoznia. Hasonló logika alapján Sasku tanácsolja közmunka lehetőségének biztosítását a munkanélküli, ám munkavégzésre alkalmas tagok számára, ahol csökkentett munkabérért kellene őket dolgoztatni, míg át nem léphetnek ismét a piaci szférába (Sasku, 1842a).

Látható, hogy Sasku igen széles szociális háló létrehozását tűzi ki célul, és hangsúlyozza, a közösség felelősséggel tartozik minden tagjáért. Mindez az utilitarista hozzáállás jegyeit mutatja, hiszen a „társasággal” szembeni legfőbb elvárás tagjai részéről, hogy hasznos legyen számukra.

\section{Konklúzió}

Sasku munkáiban megjelenő republikánus jegyek több forrásra is visszavezethetőek. Az antik jegyek közül elsősorban a köztársaságkori Róma hatása jelentős, a közösséget az élete árán is védelmező, ám mégis a békét magasztaló autonóm földműves katonapolgár ideálja az a fő motívum, mely Sasku republikanizmusát alapvetően meghatározza.

A fentiekből látható azonban, a Sasku által beszélt republikánus nyelv nem önmagában van jelen a szerző érvelésében, hanem több egyéb politikai beszédmóddal és eszmerendszerrel együttesen képezik Sasku politikai gondolkodásmódjának alapjait. Megfigyelhető a „legnagyobb rész legnagyobb boldogságát” célul kitűző utilitarizmus, a smithiánus gazdasági elveken keresztül a skót felvilágosodás is. Mégis úgy tűnik, hogy a vezérszál, melyre Sasku a tökéletes „társaság” modelljét felhúzta, a közösséget az egyén szabadságának fő őreként jelen levő republikanizmus. Sasku végig hangsúlyozza, hogy az egyén önállóságát rendkívül fontosnak tartja, azonban ahhoz, hogy az egyén önálló és szabad maradhasson, kénytelen egy „társaság” tagjává válni. A „társaság” két okból fontos a tagjai számára: azért, amit tesz értük, vagyis őrzi jogaikat, és megfelelő kereteket teremet a boldogságkeresésük számára, sőt, gondoskodik is róluk amennyiben arra ők maguk már nem képesek; illetve azért, amit nem tesz: vagyis nem avat- 
kozik be az életükbe, és lehetôvé teszi számukra hogy önállóan irányítsák életük menetét.

Fontos ugyanakkor megérteni, hogy Saskunál a „társaság” és az egyén kölcsönösen egymásra vannak utalva. Egyének nélkül nincs társaság, hiszen az, mint Sasku is írja, csak „tagjaiban áll fenn”, társaság nélkül viszont az egyén kiszolgáltatott helyzetbe kerül a környezetével szemben. Ezért aztán az a jó „társaság”, amelyik hasznos tud lenni tagjai számára, hiszen csak így nyer értelmet létezése. Ugyanígy a tagoknak is a közösség hasznos tagjává kell válnia, hogy a „társaság” teljes jogú polgáraként jogot formálhassanak annak működésének alakításába. Sasku munkássága elsősorban az egyén és a közösség egymással szembeni viszonyrendszerének meghatározására törekszik, hogy megállapítsa azt az egyensúlyi állapotot, ahol az egyén még szabad maradhat, ám egyúttal - a szerző szóhasználatával élve - ezen egyensúly megteremtésében „áll a társaságtudomány legmélyebb titka".

\section{Irodalom}

Ács T. (2005): A reformkor hadikultúrájáról. A magyar hadügy és tudomány kérdéseiról. Magyar Tudománytörténeti Intézet, Piliscsaba.

Áron L. (2003): Érvelési módok a korai utilitarizmusban. Világosság 2003/11-12.

Berlin, I. (1969): Two Concepts of Liberty.

Letöltés: 2021.03.19. Web: https://cactus.dixie.edu/green/B_Readin gs/I_Berlin $\% 20$ Two $\% 20$ Concpets $\% 20$ of $\% 20$ Liberty.pdf

Deák Á. és Kövér Gy. (2012): Egy sorsüldözött rögeszméi -Sasku Károly (1807-1869)-; in: Határon innen, határon túl;
Tanulmányok Tilcsike György 60. születésnapjára. Szombathely, 2012.

Demeter M. A. (2018): Korunk politikai filozófiája. Egyetemi Múhely Kiadó Kolozsvár, 2018.

Farre, D.M. (1979): Coerción, Consent, and the Justification of Political Power: A New Look at Locke's Consent Claim. Archives for Philosophy of Lawand Social Philosophy, Vol. 65, No. 4 (1979). pp. 521-543

https://www.jstor.org/stable/pdf/23679 304.pdf?seq $=1$

Kovács L. (1889): Gróf Széchenyi István közéletének három utolsó éve 1846 - 1848. Franklin-Társulat, Budapest.

Kónyi M. (1885): Gróf Lónyay Menyhért önéletrajzi töredéke. Budapesti Szemle, 1885. 42. köt. 102. sz. p. 350 - 351.

Lévai Cs. (2013): Hogyan Biztosítható az erényes köztársaság fennmaradása? A klasszikus republikanizmus és a skót felvilágosodás összefonódása Thomas Jefferson politikai gondolkodásában. In: Fazekas G. T., Miru Gy. és Velkey F. (szerk.): "Politica philosophiai okoskodás". Politikai nyelvek és történeti kontextusok a középkortól a 20. századig. Debreceni Egyetem Történelmi Intézet, Debrecen.

Miru Gy. (2011): Szabadság és politikai közösség. Kossuth Lajos politikai alapfogalmai. Argumentum Kiadó - Bibó István Szellemi Múhely, Budapest.

Net1: A kisújsqállási iskolában müködött rektorok. Series Rectorum Scholae

Kisújszállásiensis. Letöltés: 2021.03.19. Web: 
https:// moricz.arrabonus.hu/?page_id=1 431

Poór J. (2003): Adók, katonák, országgyúlések. 1796 - 1811/12. Universitas Kiadó.

\section{Budapest.}

Sasku K. (1841): Törvények alaptudománya. Pest

Sasku K. (1842a): A kelet és nyugat népe és a köz. intézetekról. Pest

Sasku K. (1842b): Boldogságtudomány, vagyis mimódon teheti magát az emberi nem zet lehetó legboldogabbá? Buda.

Skinner, Q. (1997): Jelentés és megértés az eszmetörténetben. In: Horkay Hörcher Ferenc (szerk.): A koramodern politikai esżmetörténet cambridge-i látképe. Tanulmány Kiadó. Pécs, 1997.

Szinnyei J.: Magyar írók élete és munkái. Letöltés: 20221.03.19. Web: https://www.arcanum.hu/hu/onlinekiadvanyok/Lexikonok-magyar-irok-eletees-munkai-szinnyei-jozsef-7891B/sA6233/sasku-karoly-A6DD9/

Takáts József (2014): A megfelelö ötvözet. Osiris Kiadó. Budapest.
Taylor, M. J. (s.a.): Centrurions in Early Rome. Letöltés: 2021.03.19. Web: https://www.academia.edu/38788743/Ce nturions_in_Early_Rome p. 9.

Tiszántúi Református Egyházkerült Levéltára: II. 1. C. 3. Kollégiumi Igazgatói Iratok: 1821500.

Williford, M. (1975): Bentham on the Rights of Women. Journal of the History of Ideas. University of Pennsylvania Press, 1975. Závodszky G. (1992): Az Egyesült Államok, mint a polgárosodás modellje a magyar liberalizmus kialakulása és térhóditása idôszakában (1830-1840). Letöltés: 2021.03.19. Web: https://www.academia.edu/37254047/Z $\%$ C3\%A1vodszky_G\%C3\%A9za_Az_Eg yes $\%$ C $3 \%$ BClt_\%C3\%81llamok_mint_a_ polg $\%$ C $3 \%$ A 1 rosod $\%$ C $3 \%$ A 1 s_modellje_ a_magyar_liberalizmuskialakul $\% \mathrm{C} 3 \% \mathrm{~A} 1 \mathrm{sa}$ _ $\% \mathrm{C} 3 \% \mathrm{~A} 9 \mathrm{~s}$ _t $\% \mathrm{C} 3 \% \mathrm{~A} 9 \mathrm{rh} \% \mathrm{C} 3 \% \mathrm{~B} 3 \mathrm{~d} \% \mathrm{C}$ $3 \% \mathrm{ADt} \% \mathrm{C} 3 \% \mathrm{~A} 1$ sa_kor $\% \mathrm{C} 3 \% \mathrm{~A} 1 \mathrm{ban} \_. d$ ocx 